\title{
TRAIL ACCREDITATION AS A MECHANISM TO ENHANCE HIKERS’ CONFIDENCE DURING DECISION-MAKING
}

\author{
LIANDI SLABBERT* AND ELIZABETH ANN DU PREEZ† \\ *Tourism Development and Marketing Division, South African National Parks, Pretoria, South Africa \\ $\dagger$ Division of Tourism Management, Department of Marketing Management, \\ University of Pretoria, Pretoria, South Africa
}

\begin{abstract}
Though regarded as a "soft" adventure activity, the growing popularity of hiking has led to increased documentation of associated risks and unfortunate incidents. Various systems are being used to facilitate adequate trail management to prevent risks, and information provision through accreditation systems provides a means to manage risk perceptions. However, little research has been done on the influence of accreditation systems on consumers' decision-making and buying behaviour within the adventure tourism context. This study took a quantitative approach to measure the importance of and future intended response towards trail accreditation among a sample of 926 hiking tourists in South Africa. A hypothetical country-wide implementation of a case study accreditation system was presented to respondents. The study indicates safety-related information as one of the key components of an accreditation system. It also demonstrates a link between trustworthy information, accreditation, and future hiking participation through addressing perceptions of risk.
\end{abstract}

\section{Key words: Hiking; Adventure tourism; Trail accreditation; Risk perception}

Introduction

A consumer's collection of perceived risks makes up a compelling element in the decision-making process. Such perceived risks include subjective uncertainty about the product itself, the place and mode of purchase, as well as financial and psychosocial consequences, and may originate from past experiences, intrapersonal attributes, awareness of the risks, and availability of information sources (Moutinho, Ballantyne, \& Rate, 2011).
This element of decision-making is particularly relevant in adventure tourism where the experience is usually accompanied by risk and where consumers seemingly desire this experience (Cater, 2006; Dickson \& Dolnicar, 2004; Ryan, 2003; Swarbrooke, Beard, Leckie \& Pomfret, 2003). Tourists seeking thrill and adventure will often travel to some of the world's most dangerous and faraway destinations in order to experience extreme emotions, take risks, and encounter novelty (Williams \& Soutar, 2009). 
Not all forms of adventure activities are perceived to have the same degree of risk. The "soft" adventure tourism activity referred to as hiking is one such example where risk is not seen as the major component of the experience sought by the participant (Kastenholz \& Rodrigues, 2007; Rupf, Haider, \& Pröbstl, 2014; Saayman \& Viljoen, 2016). Hiking takes place in various formats and is known by different names in countries across the globe, including walking, bushwalking, outdoor walking, rambling, tramping, backpacking, trailing and longdistance trailing, trekking, and hill walking. Despite it being a softer form of adventure, the growing popularity of hiking has led to increased documentation of associated risks and unfortunate incidents, classifying it is a high incident activity (Heggie \& Heggie, 2012).

The most recognized way of upholding standards in tourism is through accreditation systems. While there are numerous accreditation systems and (closely related) ecolabels in circulation in tourism today (Bentley, Page, \& Walker, 2004; Bergin \& Jago, 1999; Bergin-Seers \& Mair, 2009; Buckley, 2002; Fairweather, Maslin, \& Simmons, 2005; Font, 2002; Foster, 2003; Kozak \& Nield, 2004; Lacher, 2012; Leonard, 2011; Marchoo, Butcher, \& Watkins, 2014; Puhakka \& Siikamäki, 2012), the majority of literature around the impact of these falls outside the scope of adventure tourism. Inaccurate product information not only increases risk but also leads to unsatisfactory experiences for hikers, which in turn create managerial challenges for service providers (Beeco, Hallo, Baldwin, \& McGuire, 2011). Avoidance of perceived threats and expansion of knowledge have been proven as strategies to negotiate fears among solo hikers (Colbe, Selin \& Erickson, 2003). Services such as porters or guiding may reduce some of the unnecessary risks (Bentley \& Page, 2008). However, the role of reliable safetyrelated information provision through a platform such as an accreditation system in decision-making of hikers has not been explored.

The aim of this article is to explore whether a demand for such quality control systems exists among hikers. Understanding this demand could encourage industry adoption and aid in creating relevant offerings to these adventure tourists in line with their desired risk levels. The literature review starts off by contextualizing hiking as an adventure tourism product. It then discusses risk as a dimension of adventure and hiking tourism, followed by the role of information provision to manage risk perceptions and lastly accreditation systems as a platform providing such information. The section ends off with an overview of hiking in South Africa as study area.

\section{Literature review}

\section{Hiking as an Adventure Tourism Product}

Hiking is a popular tourist activity and takes on many forms. It is defined as "travelling on foot through the backcountry carrying all one's own supplies and equipment” (Buckley, 2006, p. 287). Hiking tourism has been allocated to various tourism subsectors by different authors, most often the subsectors of adventure tourism, sport tourism, and nature-based tourism. Adventure tourism is defined as encompassing "all types of commercial outdoor tourism and recreation with a significant element of excitement” (Buckley, 2010, p. 5), with "softer" or less risky outdoor recreation activities such as hiking also included (Buckley, 2006; United Nations World Tourism Organization [UNWTO], 2014). Sport tourism involves the traveling to a destination away from one's principal residence for the means of taking part in a sport activity on a competitive or recreational level (Standeven \& De Knop, 1999) and to observe sport at different levels of professionalism (Gibson, 2004). Ritchie and Adair's (2002) five sport tourism categories include adventure sport tourism, with hiking named as one of the activities. Nature-based tourism is described as tourism that appears in regions rich in natural attractions as well as activities coupled with natural settings (Lundmark \& Müller, 2010), with multiple authors (e.g., Chhetria, Arrowsmith, \& Jackson, 2004; Fredman, Wall-Reinius, \& Grundén, 2012; Tyrväinen, Uusitalo, Silvennoinen \& Hasu, 2014) associating hiking tourism with this subsector.

The key differentiator of adventure tourism is the presence of at least some element of risk or challenge, be it intellectual, physical, or emotional (Swarbrooke et al., 2003). For purposes of this study, hiking is framed within the context of adventure 
tourism as a "soft adventure" or the disruption of daily routines with incidences of uncertainty, insecurity, novelty, and perceived risk (Lipscombe, 1995). It has specific commonalities with other adventure tourism products: a physical challenge in nature; a leisure activity in a remote or wilderness destination; uncertain outcomes experienced in terrains and destinations often unfamiliar to the tourist; unknown environmental risks; contrasting emotions; exploration, discovery, and the notion of escapism (Mlozi \& Pesämaa, 2013; Swarbrooke et al., 2003). Like any tourism offering, hiking should be offered in a format most befitting to consumer demands (Nordbø, Engilbertsson, \& Vale, 2014). Understanding the desired levels of risk for these adventure tourists is therefore essential.

\section{Perceived Risk in Adventure and Hiking Tourism}

Risk, as perceived by consumers, can take on many different forms: physical, psychological, social, monetary, fulfillment, time, and opportunity loss (Schiffman \& Kanuk, 2007) and is based on an evaluation of possible negative events and the probability of such events occurring (Mowen \& Minor, 1998). The impact of perceived risks on tourist behavior has been researched extensively (Adam, 2015; Moutinho et al., 2011; Sharifpour, Walters, Ritchie, \& Winter, 2014) as it plays a role in the marketing of a destination (Mlozi \& Pesämaa, 2013), having the power to sway tourists' decisions regarding destination choice (Fuchs \& Reichel, 2006). While the majority of perceived risks are categorized as having a negative impact on destination visitation, some authors contend that it may also act as a motivator for travel (Mura, 2010; Mura \& Cohen, 2011). The degree to which a tourist accepts or rejects risk varies among different tourist segments with each segment having a threshold against which risk becomes intolerable (Hunter-Jones, Jeffs, \& Smith, 2007). Building trust between providers and adventure tourists through carefully considering both the perceived risks and the skills levels held by tourists is an important consideration in ensuring successful outcomes for adventure tourism providers. This was demonstrated in the case of white-water rafting, an activity that is not practiced frequently by most tourists, leaving the tourist in a vulnerable position regarding knowledge of the subject or skill to be engaged in (Zillifro \& Morais, 2004). In addition to adventure activities not being practiced frequently by tourists, many activities are not performed frequently at the same destination, most notably in hiking tourism where participants explore various new destinations each year, placing an even greater emphasis on establishing a trust relationship between hikers and supplier.

Risk in hiking tourism presents itself through different dimensions, including:

- Environmental factors: Characteristics of the environment and parameters of the path (MagyariSáska, 2014), and unpredictable outcomes in unfamiliar terrain and destinations including inadequate water supply, exposure to cold and heat, sudden weather changes, and human-animal conflicts (Bentley \& Page, 2008; Heggie \& Heggie, 2012; Magyari-Sáska, 2014, Saayman \& Viljoen, 2016; Uriely, Schwartz, Cohen \& Reichel, 2002).

- Quality of products and services: The availability and conditions of facilities and services en route vary extensively across trails. Lack of maintenance of physical structures (e.g., climbing ladders or bridges along the route), inaccurate maps, as well as a lack of quality guiding, may induce risks to hiking tourists (Bentley \& Page, 2008; MagyariSáska, 2014).

- Physical harm and reduced satisfaction: Danger of injury to the hiker such as tripping, slipping, or falling (Bentley \& Page, 2008) as well as musculoskeletal and soft tissue afflictions (Hamonko, McIntosh, Schimelpfenig, \& Leemon, 2011). Furthermore, hikers often overestimate their physical abilities (Bentley \& Page, 2008; Heggie \& Heggie, 2012) and/or underestimate the length or difficulty level of the trail, leading to a reduced visitor experience (Hugo, 1999a), injury, fatigue and discouragement, getting lost, and, often in the case of novice hikers, premature discontinuation of the activity. Health-related risks include the risk of contracting infectious diseases, gastrointestinal illnesses, and dehydration (Boulware, Forgey \& Martin, 2003).

- Social factors: Injury from other humans or theft of property is also a possibility (Colbe et al., 2003). 
Adventure tourists voluntarily accept risk as part of the experience (Morgan, Moore, \& Mansell, 2005); however, risk may not always be the main motivator for participation. It is believed that perceived risk plays a bigger role in the context of adventure tourism than the actual risk (Buckley, 2012; Cater, 2006). Buckley (2012) argued that it is rush and not risk that drives participation in skilled adventure tourism. Nevertheless, the uncertainty of the outcome remains a key motivator (Patterson \& Pan, 2007). Soft adventurers, such as hikers, find satisfaction in mastering the perceived risks through guidance of the operator as well as through a spiritual connection with nature (Williams \& Soutar, 2005). In hiking, perceived risks may be further influenced by the hiker's physical skills and abilities in overcoming challenges. The exchange between risk and competence is often explained through the concept of challenge, with adventure tourists using their skills to avoid the inherent risks of the activity (Imboden, 2012; Tsaur, Lin, \& Liu, 2013). Martin and Priest (1986) conceptualized the optimal adventure experience in their Adventure Experience Paradigm (AEP) as a peak state that is achieved through a balance of perceived risk and competence. Experiences vary across five possible scenarios: (1) devastation and disaster (risk is greater than competence and creates a perception of severe danger); (2) misadventure (risk is slightly more than competence and results from a threatening incident); (3) peak adventure (a close match between the fully engaged individual's competence and perceived risk); (4) adventure (decreased risk allows the individual to test his/her competence); and (5) exploration and experimentation (low risk allows the individual to practice skills in a relaxed state).

Tourists will alter their responses to an adventure product such as hiking when they have encountered a certain level of risk. In the case of an undesirable encounter (such as the "devastation and disaster" or "misadventure" scenarios), for example, they could employ strategies to reduce risk to a tolerable level, such as developing brand loyalty and searching for information (Mowen \& Minor, 1998; Schiffman \& Kanuk, 2007). The pursuit of information, initiated by the appearance of risk, whether perceived or real, emphasizes the importance of the availability of trustworthy and accessible information sources and is discussed subsequently.

\section{Information Provision to Manage Risk Perceptions During Decision-Making}

A considerable amount of research has been dedicated to the importance of information search as a stage in the tourist buying process and travel decision model (Chen \& Gursoy, 2000; Fodness \& Murray, 1997; George, 2004; Gursoy \& Chen, 2000; Gursoy \& McCleary, 2004; Gursoy \& Umbreit, 2004; Kerstetter \& Cho, 2004; Moutinho et al., 2011; Perdue, 1985; Snepenger, Meged, Snelling \& Worrall, 1990) as well as the factors influencing information search (Fodness \& Murray, 1997; Raitz \& Dakhil, 1989; Schmidt \& Spreng, 1996; Schul \& Crompton, 1983). One of the main reasons tourists search for information prior to taking a trip is to improve decision-making and reduce the risk associated with the uncertainty of outcomes (Hales \& Shams, 1991; Maser \& Weiermair, 1998). Information search in the pretrip stage may vary according to sociodemographic profiles of tourists (Schul \& Crompton, 1983; Sharifpour et al. 2014), motives for taking a trip, and types of tourism product classes (Jun, Vogt, \& MacKay, 2007). A relationship also exists between a tourist's risk perception and his/her prior knowledge (gained objectively from information provided; gained subjectively through past travel experience), where tourists with extensive traveling experience hold a greater degree of subjective knowledge and resultant higher selfconfidence (Jun et al., 2007; Sharifpour et al., 2014). The extent to which this applies in the hiking tourism context is still untouched in the literature.

In adventure tourism, the relationship between the availability of information and perceived risk associated with an activity or destination varies between adventure type. Some adventure seekers prefer to equip themselves with more information whereas for others uncertainty around the destination and the experience forms part of the appeal (Adam, 2015). As the perceptions and preferences of these tourists increasingly have to be recognized (Nordbø et al., 2014), the actual desired levels of risk also need to be considered (Dickson \& Dolnicar, 2004; Ryan, 2003). In hiking, this is most often lower and hikers search for information in the pretrip stage to ensure a safe and satisfactory experience while on the trip itself (such as maps and directions, safety 
information, information about weather changes, trail/ road conditions, nearest exit routes in case of emergency, etc.). Inaccurate or lacking information may place hikers in uncomfortable situations, such as unfit hikers in the group not being able to complete the trail or roads found not being traversable, or may lead to life-threatening situations in extreme circumstances (Ernest, Level, \& Culbertson, 2005).

Hikers tend to plan their tour in greater detail than other outdoor activities, preferring traditional information media such as printed maps and tour guides (Rupf et al., 2014). Thapa, Graefe, and Absher (2002) found that forest visitors focus on "orientation" needs when seeking information such as the location's assets (activities, events, and places to visit) as well as information that empower visitors to feel more secure in this environment. Instrumental needs, such as information about parking, permits, and operating hours, are slightly less important. Third-party information has also been shown to significantly affect destination choice regarding sustainable tourism products (Luthe \& Schläpfer, 2011). This pursuit of trustworthy information, initiated by the appearance of risk, whether perceived or real, emphasizes the importance of the availability of credible and accessible information sources.

\section{The Role of Accreditation Systems as Credible Information Source}

The supply of information can affect consumer trust in a number of ways. Zillifro and Morais (2004) found that the more information is shared between tourists and providers (in a two-way direction), the more likely tourists are to trust the provider. When this communication channel is lacking, information asymmetry occurs in which the tourist has deficient understanding of the product or service offering, leading to moral hazards (tourists feel that they have been taken advantage of) and mistrust. On the positive side, a provider can increase the transparency between itself and the tourist by providing information that gives a trustworthy account of the quality of the service or activity that can be expected. An extensive range of accreditation systems and certification programs exists across the tourism industry and in different regions with the aim of fulfilling this need for adequate and reliable product/service information. These systems arguably provide consumers with information that allows alternative choices (Buckley, 2002). Although evidence does exist for the fact that accreditation is a successful strategy to build consumer trust in the case of nontourism products such as organic food and fairtrade-labeled products (Howard \& Allen, 2008), this link is lacking within tourism and leisure. A recent study by Marchoo et al. (2014) found that accreditation may have significant impacts on perceived tour value, trust, and tour booking intention. Still, consumer attitude (behavioral intention) is not necessarily a reliable predictor of future buying behavior (Leonard, 2011). Although tourists may regard accreditation systems as a sign of quality, findings on the impact of these systems on buying behavior and active demand for such systems remain inconclusive and disparate (Buckley, 2002; Chia-Jung \& Pei-Chun, 2014; Lacher, 2012; Leonard, 2011). Though it has been proven that tourists approve of and recognize a well-established system such as Green Globe 21 (Marchoo et al., 2014), demand for environmental brands takes decades to develop (Leonard, 2011), and the variety of ecolabels available has left tourists indifferent (Font, 2002).

Within the adventure tourism context accreditation and grading systems have been researched mostly from the operators' perspective as being a vehicle through which to address the issue of public liability or through which to encourage standardization and quality of offerings (Beeton, 2001; Morgan \& Dimmock, 2006; Morgan \& Fluker, 2003). Within the context of hiking, alternatives to accreditation systems exist and vary in format and ownership across countries; for example the state-operated USDA Forest Service Standard Trail Plans and Specifications focuses on trail construction and maintenance (US Forest Service, 2016) or the voluntary Australian Walking Track Grading System aimed at providing difficulty-level grading (Edwards, 2016). Hiking trails, clubs, and regional destination marketers may also develop their own more simplistic trail difficulty grading systems. However, little is known about tourists' perceptions of these systems in terms of their usefulness and perceived credibility. A study in Australia concluded that tourists do not pursue a product or service based on whether an operator is accredited (Foster, 2003) despite a 
significant percentage indicating that they would make use of an accredited service provider if they were aware of its existence. Likewise, an exploratory study by Bergin and Jago (1999) found the accreditation of adventure tour operators, although positively received by consumers, would not necessarily result in consumer preference.

Research investigating the impact of accreditation on adventure tourist decision-making in general is insufficient, with no literature exploring its impact in a hiking tourism context. Therefore, the following research questions are presented:

1. How important is the accreditation of hiking trails in hikers' decision-making?

2. Does a hiker's safety perceptions and hiking experience influence the level of importance of trail accreditation?

3. Does trail accreditation influence future uptake of hiking?

4. Which information elements of a trail accreditation system are most influential in hikers' decision-making? Specifically, how important is safety-related information?

5. Do safety perceptions influence the relationship between information provision and future uptake of hiking?

\section{Hiking in South Africa as Study Area}

To answer the research questions, empirical research was conducted in South Africa. With a total estimated 6,352 miles of footpaths, the country offers some of the most spectacular hiking opportunities in the world (BuzzFeed, 2014; "Top 10 Hiking Trails," 2014; Walkopedia, 2015) and trails such as the North Drakensberg Traverse rank among the world's best (National Geographic Society, 2014). Similar to the US and Canada (American Hiking Society, 2014), hiking is the preferred term used though walking and climbing may also be used to describe the activity (Hartwright, 2014; Lundy, 2012; Olivier, 2010). It is generally understood as the act of walking along trails or footpaths carrying a ruck sack, backpack, or daypack containing one's supplies and equipment (Brand South Africa, 2003; Hugo, 1999b; Olivier, 2010).

Access to the countryside of South Africa is almost always controlled (Hugo, 1999b), contrary to many other countries. South Africa offers a range of different types of hiking tourism products. These include backpacking trails (Olivier, 2010), day walks and day hikes (Hartwright, 2014), guided walks (South African National Parks, 2015), slack packing/luxury hiking/serviced trails, traditional trailovernight hikes, long distance trails, and wilderness trails (Olivier, 2010). Most trails consist of cleared paths in the veld, designed in such a way as to minimize contact with populations and artificial structures and generally provide accommodation in the form of huts with basic facilities (Hugo, 1999b). The location of trails usually necessitates hikers to travel away from home (normal place of residence) for more than $24 \mathrm{hr}$, placing them within the category of being a tourist. Trails involving overnight stays are prebooked and a permit is issued to hikers as a right to traverse the land. Hiking facilities are provided and marketed through various entities: stateowned conservation authorities such as South African National Parks; regional and provincial conservation agencies; commercial forestry and timber companies; local governments or municipalities; agents such as Jacana Travel Marketing and Reservations, who manages the marketing and booking of around 150 trails; adventure tourism companies; private game reserves and game farms; as well as private land owners and farmers. According to the Hiking Organisation of Southern Africa (HOSA), one of the biggest threats to the industry is the deterioration in the quality of trails (personal communication, HOSA president, 2013). Trail owners often neglect to inform hikers of any changes in the conditions of trails, which is evident from numerous complaints received by HOSA each year from hikers who report incidences of information being misleading, inaccurate, or outdated. In 2006 the independent Green Flag Accreditation System (Green Flag; http://greenflagtrails.co.za/) was implemented, focusing on assessing the responsible management and marketing of trails. It is the only trail accreditation system in Africa, is promoted as the official accreditation system of HOSA, and receives support from the World Trails Network (WTN) as well as the major conservation agencies in South Africa (personal communication with M. L. Hugo, 2015). To date, it has also been implemented outside of South Africa including in Peru, Mozambique, Swaziland, and St. Helena. Trails in Namibia and Nepal have recently applied for Green Flag status. 


\section{Methodology}

Quantitative research was conducted in the form of internet-mediated self-completion questionnaires distributed to the targeted population of hiking tourists. As the right to traverse South African land can only be acquired through the purchase of a permit (prebooked or obtained on arrival in case of day walks), in this context the hiking tourist population was defined as all individuals participating in organized hiking activities on trails within the borders of South Africa. Because no reliable databases of hiking tourists exist in South Africa and the size of the population is therefore unknown, self-selection as a form of nonprobability sampling was used. In this form of volunteer sampling cases are invited to participate through advertising the study through suitable media types and data collected from those who respond (Saunders, Lewis, \& Thornhill, 2012). Data collection was undertaken between the months of February and April in 2015. Internet-mediated access was obtained through various channels. Firstly, 103 hiking clubs based in South Africa were formally requested to distribute a link to the questionnaire among club members. Next, the South African National Parks' Wild Card membership program distributed the survey to its members by advertising the survey in their e-newsletter and on their social media sites. In addition, three local commercial entities that manufacture and sell outdoor recreational and sports apparel and equipment advertised the survey on their social media pages and monthly e-newsletters. A total of 926 questionnaires were deemed usable, though not all respondents completed all of the questions ( $N$ values indicated separately for each analysis).

Demographical information related to age, gender, province of residence, and population group was collected from the sample of hikers. The online structured questionnaire consisted of primarily closed-ended questions. Table 1 provides a layout of the questionnaire, scales used and data analysis conducted. The following hypotheses were tested and are also indicated in Table 1.

H1: There is a relationship between hikers' purchase levels and the level of importance of accreditation.

H2: There is a relationship between hikers' safety perceptions and the level of importance of accreditation.
H3: There is a difference in hikers' intended purchases if trustworthy information is available on the quality of facilities.

H4: There is a difference in hikers' intended purchases if information is available on the safety of trails.

H5: There is a difference in hikers' intended purchases if information is available on difficulty level of trails.

H6: The willingness among hikers to increase intended purchases if trustworthy information on the safety of trails is available differs between hikers with different safety perceptions.

Initial descriptive statistics were used to describe the data for the four scales used: safety perceptions of hiking, importance of trail accreditation, the influence of trustworthy information on purchase intention, and the importance of the various information aspects. Thereafter three different statistical tests were conducted based on the nature of the data. To test H1 hikers were grouped into distinct categories based on levels of hiking activity (frequent vs. infrequent based on the average number of hikes per year) and level of importance of accreditation (unimportant vs. important). The Pearson chi-square test was used to test for meaningful relationships between two nominal variables (Saunders et al., 2012). As a robust nonparametric test, chi-square was suitable for the data type, the sample size (large enough in each cell of the cross-tabulation) as well as the fact that the data did not meet the requirements of parametric tests (normality and equal variance) as well as collapsing the continuous data into a smaller number of categories. A second nonparametric test, the Kruskal-Wallis test, was used (in the place of the parametric one-way ANOVA) to test $\mathrm{H} 2$ and H6, comparing the means scores of a continuous variable (importance of accreditation and purchase intention) between three or more groups (respondents grouped according to safety perceptions; again collapsing a continuous variable into smaller categories). The third nonparametric test, the binomial, was used to test $\mathrm{H} 3$, H4, and H5. This exact probability test was used to test the differences between sample proportions and a given proportion, in this case whether the differences in sample proportions were more than $50 \%$ (Lewis-Beck, Bryman, \& Liao, 2003). The aim was to determine whether the majority of respondents (more than $50 \%$ ) fell into the category of being 
Table 1

Data Analysis

\begin{tabular}{|c|c|c|}
\hline Aspect Measured & Scale Used & Data Analysis ${ }^{a}$ \\
\hline $\begin{array}{l}\text { Safety perceptions of hiking in South } \\
\text { Africa }\end{array}$ & $\begin{array}{l}\text { Likert scale (1 = strongly disagree; } \\
5=\text { strongly agree })\end{array}$ & Descriptive statistics (mean scores) \\
\hline $\begin{array}{l}\text { Perceived importance of trail } \\
\text { accreditation }\end{array}$ & $\begin{array}{l}\text { Likert scale }(1=\text { not important at all; } \\
5=\text { extremely important })\end{array}$ & Descriptive statistics (mean scores) \\
\hline $\begin{array}{l}\text { Influence of hiking purchase levels on } \\
\text { perceived importance of trail accredi- } \\
\text { tation (H1) }\end{array}$ & $\begin{array}{l}\text { Categories (frequent, infrequent); Two } \\
\text { categories created from initial Likert } \\
\text { scale (not important/important) }\end{array}$ & Chi-square (Saunders et al., 2012) \\
\hline $\begin{array}{l}\text { Influence of safety perceptions on per- } \\
\text { ceived importance of trail accredita- } \\
\text { tion (H2) }\end{array}$ & $\begin{array}{l}\text { Three categories created from initial } \\
\text { Likert scale (unsafe/neutral/safe); } \\
\text { Likert scale ( } 1=\text { not important at all; } \\
5 \text { = extremely important) }\end{array}$ & $\begin{array}{l}\text { Kruskal-Wallis (testing difference } \\
\text { in scale rating between more } \\
\text { than two categories) (Leedy \& } \\
\text { Ormrod, 2014) }\end{array}$ \\
\hline $\begin{array}{l}\text { The influence of trustworthy informa- } \\
\text { tion regarding the quality of facilities } \\
\text { on intended purchases }\end{array}$ & $\begin{array}{l}\text { Likert scale }(1=\text { would not influence } \\
\text { hiking activity at all; } 5=\text { would defi- } \\
\text { nitely go hiking more })\end{array}$ & Descriptive statistics (mean scores) \\
\hline $\begin{array}{l}\text { The importance of different informa- } \\
\text { tion aspects of an accreditation system }\end{array}$ & $\begin{array}{l}\text { Likert scale }(1=\text { not important at all; } \\
5=\text { extremely important })\end{array}$ & Descriptive statistics (mean scores) \\
\hline $\begin{array}{l}\text { The influence of trustworthy informa- } \\
\text { tion regarding the quality of facilities } \\
\text { on intended purchases (H3) }\end{array}$ & $\begin{array}{l}\text { Two categories (provided/not provided); } \\
\text { Two categories created from initial scale } \\
\text { (no influence/definite influence) }\end{array}$ & $\begin{array}{l}\text { Binomial test (testing difference in } \\
\text { sample proportion and given pro- } \\
\text { portion (Lewis-Beck et al., 2003) }\end{array}$ \\
\hline $\begin{array}{l}\text { The influence of trustworthy informa- } \\
\text { tion regarding the safety of trails on } \\
\text { intended purchases (H4) }\end{array}$ & $\begin{array}{l}\text { Two categories (provided/not provided); } \\
\text { Two categories created from initial scale } \\
\text { (no influence/definite influence) }\end{array}$ & $\begin{array}{l}\text { Binomial test (testing difference in } \\
\text { sample proportion and given pro- } \\
\text { portion (Lewis-Beck et al., 2003) }\end{array}$ \\
\hline $\begin{array}{l}\text { The influence of trustworthy informa- } \\
\text { tion regarding the difficulty level of } \\
\text { trails on intended purchases (H5) }\end{array}$ & $\begin{array}{l}\text { Two categories (provided/not provided); } \\
\text { Two categories created from initial scale } \\
\text { (no influence/definite influence) }\end{array}$ & $\begin{array}{l}\text { Binomial test (testing difference in } \\
\text { sample proportion and given pro- } \\
\text { portion (Lewis-Beck et al., 2003) }\end{array}$ \\
\hline $\begin{array}{l}\text { Willingness to increase hiking purchase } \\
\text { levels among hikers with different } \\
\text { safety perceptions if safety informa- } \\
\text { tion is made available (H6) }\end{array}$ & $\begin{array}{l}\text { Three categories created from initial } \\
\text { Likert scale (unsafe/neutral/safe); Likert } \\
\text { scale }(1=\text { would not influence hiking } \\
\text { activity at all; } 5=\text { would definitely go } \\
\text { hiking more) (filter = safety information) }\end{array}$ & $\begin{array}{l}\text { Kruskal-Wallis (testing difference } \\
\text { in scale rating between more } \\
\text { than two categories) (Leedy \& } \\
\text { Ormrod, 2014) }\end{array}$ \\
\hline
\end{tabular}

Significance tested at the 90\% confidence level.

willing to increase hiking purchases if a specific type of information was provided (quality of facilities, safety of trail, difficulty grading). The preempting of the column proportions is what distinguishes the binomial test from the chi-square where the difference in proportions is not given.

\section{Results}

\section{Demographics of Respondents}

Respondents from all age categories (aged 18 years and older) were represented in the sample (presented in Table 2). The majority (68\%) of respondents were between 30 and 59 years of age with another $20 \%$ falling within the 60 years and older category. The sample was further made up of slightly more males (56\%) than females (44\%).

\section{Perceptions About Hiking Conditions in South Africa}

As a starting point it was necessary to investigate some of the perceptions held by hikers who embark on trails in South Africa. Only those perceptions that relate to the availability of information, 
Table 2

Demographics of the Sample

\begin{tabular}{lr}
\hline Category & Percentage \\
\hline Age & \\
$18-29$ years & $13 \%$ \\
$30-39$ years & $21 \%$ \\
$40-49$ years & $20 \%$ \\
$50-59$ years & $26 \%$ \\
60 years or older & $20 \%$ \\
Gender & \\
Male & $56 \%$ \\
Female & $44 \%$ \\
Population group & \\
Black African & $3 \%$ \\
Colored & $5 \%$ \\
Indian/Asian & $3 \%$ \\
White & $87 \%$ \\
Other & $3 \%$ \\
Province of residence & \\
Eastern Cape & $5 \%$ \\
Free State & $2 \%$ \\
Gauteng & $34 \%$ \\
KwaZulu-Natal & $12 \%$ \\
Limpopo & $1 \%$ \\
Mpumalanga & $3 \%$ \\
Northern Cape & $1 \%$ \\
North West & $1 \%$ \\
Western Cape & $40 \%$ \\
Outside RSA & $1 \%$ \\
\hline
\end{tabular}

quality of trails, and safety on trails are discussed briefly (Fig. 1).

Slightly more than half of the respondents (52\%) agreed information on key trail facilities (such as accommodation, restrooms, equipment at the hut or camp) was available for most trails prior to booking $(M=3.84)$. Fewer hikers $(40 \%)$ agreed with the statement that the difficulty levels and maps provided to hikers represent a reliable account of the actual trail conditions $(M=3.17)$. Most participants (45\%) disagreed with the statement that feedback mechanisms to report on the quality of trails were in place and easily accessible $(M=2.69)$. Two thirds of participants perceived the trails they have hiked to date as generally well managed $(M=3.57)$. However, a substantial $44 \%$ of hikers believed the conditions of trails in general in South Africa have been deteriorating over the last couple of years $(M=3.38)$. The safety of hiking in South Africa is of concern among the majority of participants with only $36 \%$ of respondents feeling confident that it is a safe activity to embark on $(M=3.05)$.

\section{Perceived Importance of Accreditation in Decision-Making}

Prior to presenting respondents with the key information attributes of Green Flag, hikers' perceptions of the importance of trail accreditation during decision-making (before booking or purchasing steps) were measured, providing a baseline for determining the need of an accreditation system in hiking. This was useful in the context of South African hiking where access to trails is almost always purchased. The results (Fig. 2) indicate that the majority of hikers surveyed (64\%) regard independent trail accreditation as important, very important, or extremely important when deciding on the trails to hike.

\section{The Influence of Hiking Purchase Levels on the Importance of Accreditation (H1)}

To test whether the importance of accreditation is influenced by a hiker's purchase levels (accepting the fact that all trails in South Africa require a purchase), the frequencies of each category of hikers, presented in a cross-tabulation (Table 3), was tested for significant differences. In order to distinguish between frequent and infrequent hikers, respondents were asked how many trails they embarked on in a typical year. A cumulative $40 \%$ of respondents said they hiked six or more trails in a typical year, suggesting that this group purchases a hiking permit at least every second month of the year. Respondents from this group were then categorized as frequent hikers with the remaining $60 \%$ of hikers regarded as infrequent.

As indicated in Table 4, H1 (There is a relationship between hiking purchase levels and the level of importance of accreditation) is accepted ( $p=0.001$ ), with infrequent hikers indicating accreditation as more important than frequent hikers.

\section{The Influence of Perceptions About the Safety of Hiking on the Importance of Accreditation (H2)}

Hikers' beliefs about the safety of hiking in South Africa can arguably result in a greater demand for the independent accreditation of trails. It is postulated that those who disagree that hiking in South Africa is safe place a greater importance on accreditation of trails. Respondents who strongly disagreed 


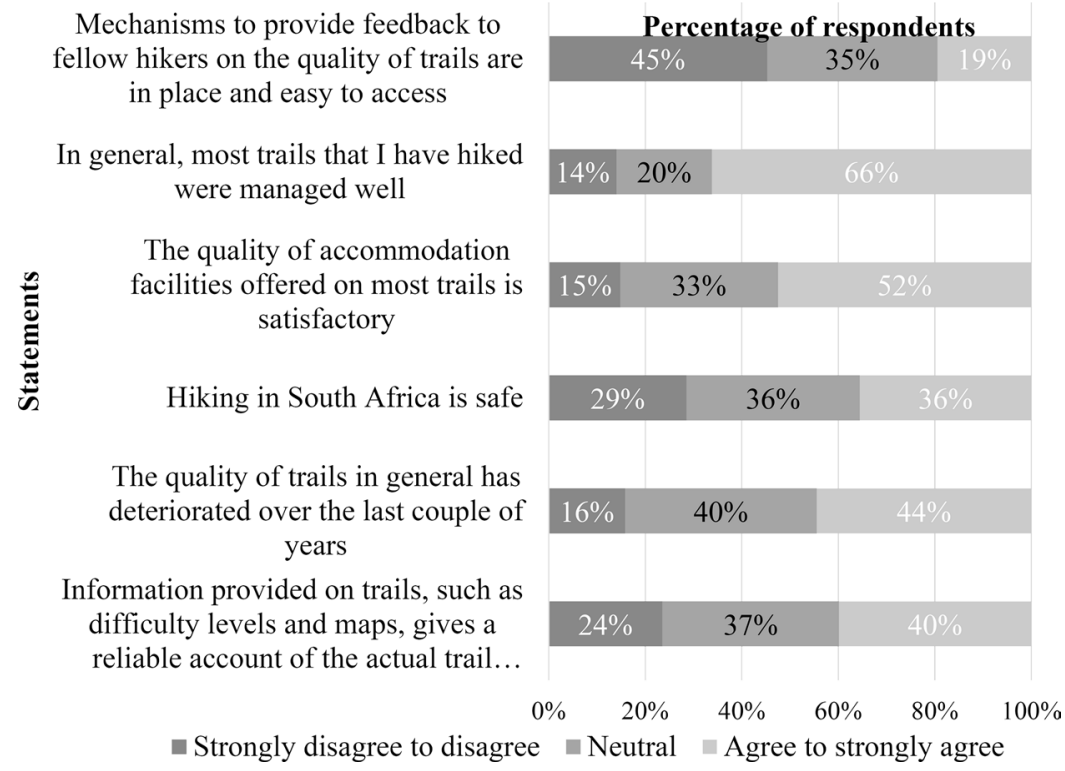

Figure 1. Perceptions of hiking conditions in South Africa $(N=861)$.

or disagreed on the Likert scale with the statement that hiking in South Africa is safe were categorized as category 1 . Category 2 represented those neither agreeing nor disagreeing with the statement. Those who agreed or strongly agreed made up category 3 (Table 5).

Based on the test result, $\mathrm{H} 2$ (There is a relationship between hikers' safety perceptions and the level of importance of accreditation) is accepted, indicating that the perception of the safety of trails has an influence on the importance placed on the accreditation of trails.

\section{Potential Influence of Accreditation on Future Purchase Behavior}

Respondents were presented with a graphical representation of the key information outcomes from the Green Flag system (Fig. 3) and asked to rate to what extent their current hiking purchase levels would

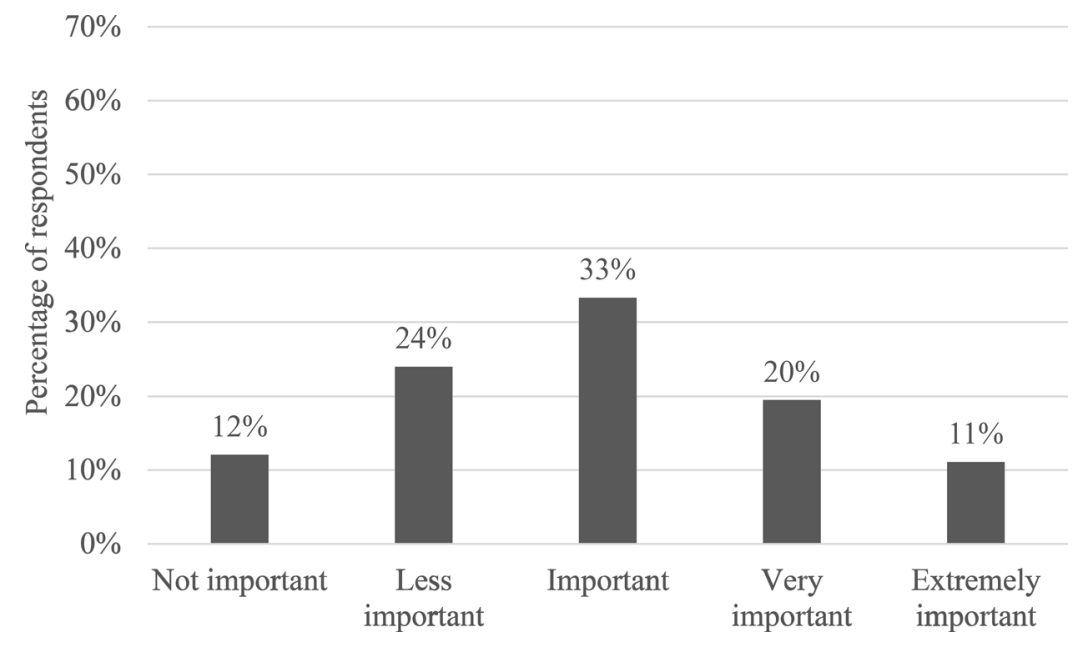

Figure 2. Importance of independent accreditation in decision making. 
Table 3

Cross-Tabulation of Importance of Accreditation by Hiking Activity Levels

\begin{tabular}{lccr}
\hline Hiking Activity Level & Not Important or of Little Importance & Important to Extremely Important & Total \\
\hline Infrequent $(N)$ & 174 & 366 & 540 \\
Frequent $(N)$ & 150 & 201 & 351 \\
Total $(N)$ & 324 & 567 & 891 \\
\hline
\end{tabular}

change if all trails in South Africa were accredited and a trustworthy description of trail attributes was available in such a format as presented.

Reaching a mean value of 3.54 , there is evidence to suggest that trail accreditation may influence future participation in hiking. As seen in Figure 4, $64 \%$ of participants reported trail accreditation would likely positively influence their hiking buying behavior, either by considering hiking more frequently or actually intending on doing so. More than a quarter (27\%) said a widespread presence of trail accreditation would lead to an increase in hiking purchases, whereas $37 \%$ would consider increasing hiking purchases. Less than $10 \%$ of hikers surveyed were certain accreditation would have no influence on their current hiking purchase levels.

\section{The Importance of Different Information Elements of an Accreditation System}

Hikers take into consideration various different factors before deciding which trails to hike. Table 6 indicates the mean values for each of the 19 information elements, ranked in order of importance.

With the exception of three areas (cell phone network coverage, services available on the trail, proximity to amenities), respondents rated all of the information items as important to very important. Judging by mean values that reached 3.6 and above (items leaning more towards the "very important" category than "important"), the most important information needs for decision-making included maps and directions, information related to the safety of the trail, duration of the trail (hours/days), length of the trail (distance), availability of water on the trail, the trail type (ramble/day walk/overnight trail/ long distance), the level of scenic beauty that can be expected, the environmental character of the trail (pristine/natural/rural/semiurban), and the trail difficulty level. Looking at the percentage of respondents who rated an item as extremely important (Table 6), the most critical pieces of information were safety information (39\%), availability of water (37\%), maps and directions (36\%), duration of the trail (34\%), and length of the trail (32\%).

\section{The Influence of Different Information Categories on Future Purchase Behavior (H3, H4, H5)}

The potential influence of the provision of different information aspects was tested in terms of hikers' future intended purchase levels. Three key areas of information related to the management of risk perceptions were focused on the quality of facilities, the safety of trails, and a difficulty level that has been independently graded. The proportion of hikers likely to increase their hiking purchase levels should trustworthy information be available on the three key areas is graphically displayed in Figure 5.

Of the three areas measured, the information area that may have the most positive impact on hiking buying behavior is trustworthy information about the safety of the trail, reaching a mean value of 3.77. A third of hikers reported they will definitely go hiking more should trustworthy information be available regarding the safety of trails, with another $37 \%$ saying they would consider hiking more. This corresponds well with the percentage

Table 4

Association Between Importance of Accreditation and Frequency of Hiking

\begin{tabular}{|c|c|c|c|}
\hline & Value & $d f$ & $\begin{array}{l}\text { Asymptotic Significance } \\
\text { (Two-Sided) }\end{array}$ \\
\hline $\begin{array}{l}\text { Pearson chi-square } \\
N \text { of valid cases }\end{array}$ & $\begin{array}{l}10.160^{\mathrm{a}} \\
891\end{array}$ & 1 & 0.001 \\
\hline
\end{tabular}

Computed only for a $2 \times 2$ table. ${ }^{\text {a Zero cells }(0.0 \%) \text { have }}$ expected count less than 5 . The minimum expected count is 127.64 . 


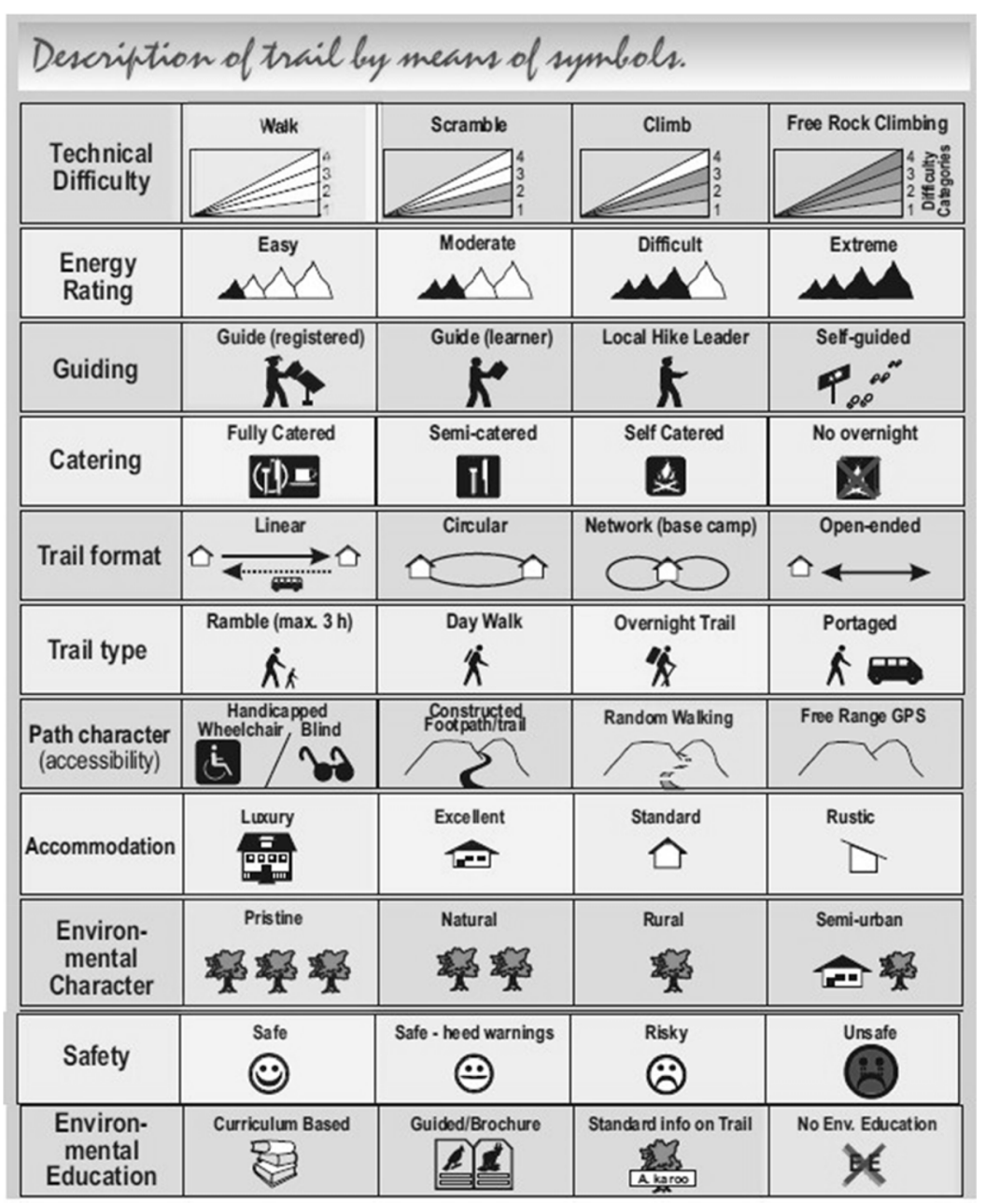

Figure 3. Green Flag summary of trail attributes.

Table 5

Importance of Accreditation and the Perception Regarding Safety

\begin{tabular}{lcc}
\hline Category & N & Mean Rank \\
\hline 1 & 246 & 455.28 \\
2 & 309 & 436.19 \\
3 & 306 & 406.24 \\
Total & 861 & \\
\hline
\end{tabular}

Test statistics: Chi-square $=5.879, d f=2$, asymp. sig. $=0.053$. of hikers who disagreed with the statement that hiking in South Africa is safe (29\%). Trustworthy information on the quality of the facilities on the trail showed the second highest potential to influence future hiking purchase levels (mean value of 3.29). Almost $20 \%$ of participants would definitely increase their purchase levels and an appreciable proportion (36\%) said they would contemplate going hiking more if trustworthy information was available regarding the quality of accommodation and ablution facilities. Fifty percent of participants would either consider or definitely increase hiking purchases should the difficulty level of trails be independently rated. 


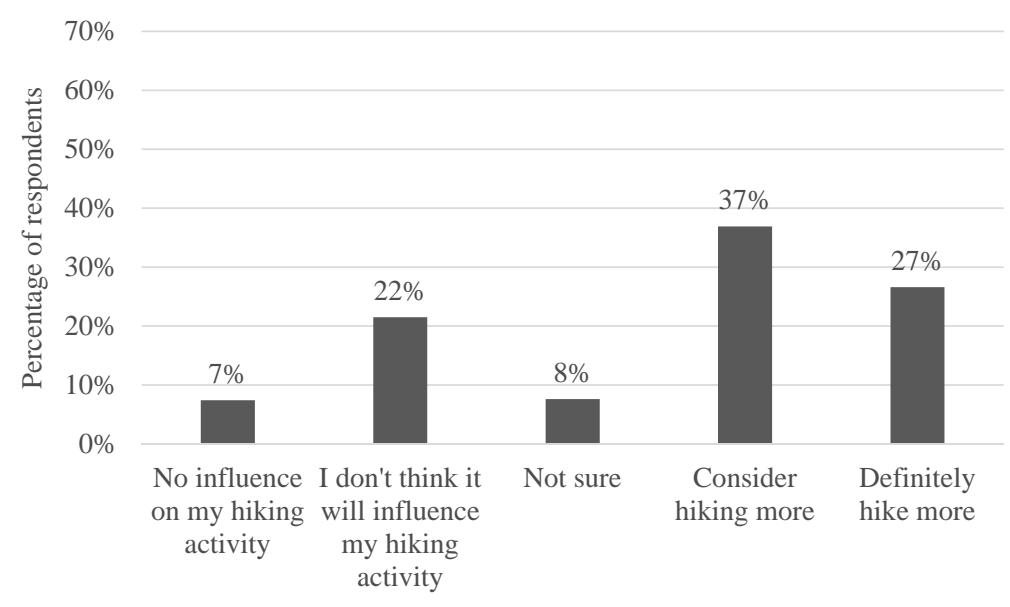

Figure 4. Influence of accreditation on future purchase behavior of hikers $(N=913)$.

The relationships between these three elements of information and future hiking buying behavior were also tested for statistical significance (Table 7).

The results from the binomial tests reveal that two of the hypotheses are accepted: H3 (There is a difference in the future purchase levels among hikers if trustworthy information is available on the quality of facilities) ( $p=0.007)$ and $\mathrm{H} 4$ (There is a difference in the future purchase levels among hikers if information is available on the safety of trails $(p=0.000)$. In both cases the proportion of hikers who said that they would either consider or definitely go hiking more is significantly greater than those saying it would either have no influence or they were not sure whether or not it would influence their hiking buying behavior.

\section{Willingness to Increase Hiking Purchase \\ Behavior Among Hikers With Different \\ Safety Perceptions (H6)}

Lastly, the relationship between the provision of safety-related information and future hiking purchase levels among hikers with different safety perceptions was tested. (Table 8).

As indicated in Table 8, H6 (The willingness to increase hiking purchase levels if trustworthy information on the safety of trails is available differs between hikers with different safety perceptions) is accepted $(p=0.000)$. Studying the mean scores, it can further be concluded that respondents who perceived hiking to be unsafe (category 1) tend to have stronger considerations towards increasing their purchase levels.

\section{Discussion and Conclusion}

This study explored the importance of safety information to manage risk perceptions in hiker

Table 6

Important Information When Deciding on Which Trails to Hike $(N=926)$

\begin{tabular}{ll}
\hline Information Area & Mean \\
\hline Maps and directions & $\mathbf{4 . 0 0}$ \\
Safety information & $\mathbf{3 . 9 4}$ \\
Duration of trail & $\mathbf{3 . 9 0}$ \\
Length of the trail & $\mathbf{3 . 9 0}$ \\
Availability of water & $\mathbf{3 . 8 6}$ \\
Trail type & $\mathbf{3 . 6 6}$ \\
Level of scenic beauty & $\mathbf{3 . 6 6}$ \\
Environmental character & $\mathbf{3 . 6 5}$ \\
Difficulty rating & $\mathbf{3 . 6 1}$ \\
Location and setting & 3.55 \\
Price of trail & 3.55 \\
Environmental sustainability & 3.51 \\
Accommodation facilities & 3.39 \\
Trail format & 3.38 \\
Type of accommodation & 3.18 \\
Environmental information & 3.07 \\
Cell phone network coverage & 2.59 \\
Services available on the trail & 2.57 \\
Proximity to amenities & 1.967 \\
\hline
\end{tabular}




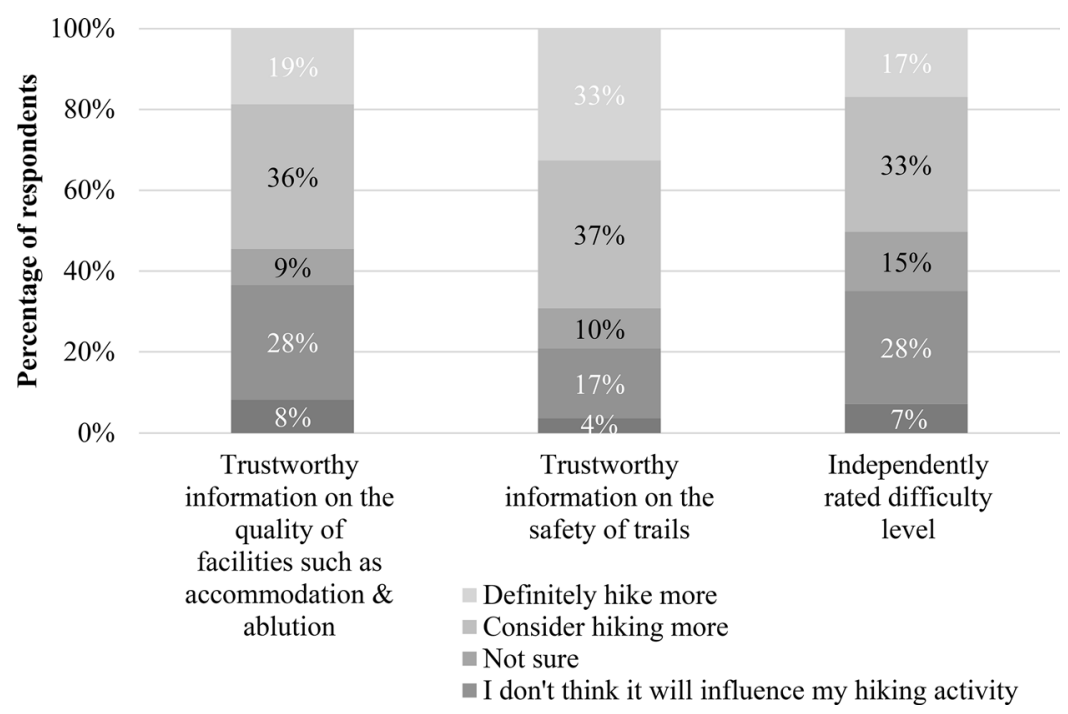

Figure 5. Influence of trustworthy information on future purchase behavior $(N=913)$.

decision-making and the role that an accreditation system could play in encouraging future purchase behavior through strengthening consumer confidence. Although the literature is not in agreement as to whether accreditation can influence consumer decision-making and buying behavior (Foster, 2003; Lacher, 2012; Leonard, 2011; Marchoo et al., 2014), this article provides support for the value of trail accreditation models in promoting consumer confidence in the case of hiking tourism, although actual purchase behavior or intentions were not measured.
The relationship between hiking purchase levels and the level of importance of accreditation proved to be significant, with infrequent hikers rating accreditation as more important than frequent hikers. This supports literature indicating that subjective knowledge gained through travel experience brings a level of confidence (Jun et al., 2007; Sharifpour et al., 2014), reduces the need for external sources (Kerstetter \& Cho, 2004), and is a very important factor to manage perceived risk in the decision-making process (Moutinho et al., 2011). The relationship between

Table 7

Willingness to Increase Activity if Trustworthy Information Was Available

\begin{tabular}{|c|c|c|c|c|c|}
\hline & Category & $N$ & Observed Prop. & Test Prop. & Exact Sig. (Two-Tailed) \\
\hline \multicolumn{6}{|c|}{$\begin{array}{l}\text { H3: Information on the facilities } \\
\text { (accommodation \& ablution) }\end{array}$} \\
\hline Group 1 & 1.00 & 415 & 0.45 & 0.50 & 0.007 \\
\hline Group 2 & 2.00 & 498 & 0.55 & & \\
\hline Total & & 913 & 1.00 & & \\
\hline \multicolumn{6}{|c|}{ H4: Information on the safety of trails } \\
\hline Group 1 & 2.00 & 632 & 0.69 & 0.50 & 0.000 \\
\hline Group 2 & 1.00 & 281 & 0.31 & & \\
\hline Total & & 913 & 1.00 & & \\
\hline \multicolumn{6}{|c|}{ H5: Information on the difficulty level of trails } \\
\hline Group 1 & 1.00 & 454 & 0.50 & 0.50 & 0.895 \\
\hline Group 2 & 2.00 & 459 & 0.50 & & \\
\hline Total & & 913 & 1.00 & & \\
\hline
\end{tabular}

Note: Significant differences indicated in bold. 
Table 8

Willingness to Increase Activity if Trustworthy Safety Information Was Available

\begin{tabular}{lcc}
\hline Category & $N$ & Mean Rank \\
\hline 1 & 246 & 455.28 \\
2 & 309 & 436.19 \\
3 & 306 & 406.24 \\
Total & 861 & \\
\hline
\end{tabular}

Test statistics: Chi-square $=35.261, \quad d f=2$, asymp. sig. $=0.000$.

hikers' safety perceptions and the level of importance of accreditation were also significantly related, where participants who had stronger negative perceptions about the safety of hiking conditions placed a greater value on the accreditation of trails.

The importance of independent accreditation of trails was measured and found to be perceived as a valuable discriminator in decision-making among hikers. The most important information prior to booking a trail (purchasing the service) included maps and directions, the safety of the trail, the effort required on the trail (length, distance, and difficulty level of the trail), availability of water, and trail type, as well as the scenic beauty and environmental character of the trail. Statistical testing indicated that the provision of trustworthy information regarding the quality of facilities and safety-related information could potentially encourage increased hiking purchases in the future. This supports previous research on the importance of these two aspects as the main perceived risks associated with hiking (Heggie \& Heggie, 2012; Magyari-Sáska, 2014) and the role it can play in assisting hikers in negotiating perceived risks to ensure continued uptake of the activity (Colbe et al., 2003). While the difficulty grading of a trail was regarded as one of the most important items in decision-making, the supply of trustworthy information about the difficulty grading of trails were not found to influence hikers' intentions to increase future purchase levels. It is acknowledged that discrepancies may exist between hikers' stated intentions and actual purchase behavior, particularly where respondents chose the socially desirable answer (Miller, 2003). However, given the link between the importance of information and decision-making demonstrated in this article, the data presented here suggest that independent trail accreditation could positively influence future buying behavior among hiking tourists.

Furthermore, it was found that participants who perceived hiking to be unsafe had stronger considerations towards increasing their future hiking purchases should trustworthy information on the safety of trails be available. The results indicate that the perception of a risk in hiking can influence a hiker's intention to act on the availability of credible information regarding the risk in question - in this case risks associated with safety. Data suggest that a link exists between the perception of safety and the value placed on objective knowledge, which emphasizes the role of trail accreditation in reducing perceived risks during the decision-making process. This is supported by the finding that those who perceived hiking conditions in South Africa to be unsafe considered independent accreditation as more important in decision-making than those who perceived it as being safe. Furthermore, it was determined that the perception of risk in hiking influenced hikers' intention to act positively should credible information regarding the risk in question-in this case safety-be available. This finding supports research that hikers may not regard risk as major component of the desired experience (Kastenholz \& Rodrigues, 2007; Rupf et al., 2014; Saayman \& Viljoen, 2016), suggesting that hikers’ peak experiences fall within the "adventure" and "exploration and experimentation" scenarios of the Adventure Experience Paradigm (Martin \& Priest, 1986). This emphasizes the importance of information provision through a credible source to bring perceived risk levels in line with hikers' competencies.

In conclusion, the independent accreditation of trails could potentially assist in increasing hiking tourism spending. Support is provided for the notion that the purchase of hiking experiences can be encouraged if hikers' risk perceptions are adequately addressed through an independent information source such as an accreditation system. The study findings are limited by a number of factors. Firstly, the use of convenience sampling limits the generalizability of the findings to the wider population. The influence of other factors relevant to the case study context, namely costs involved (permits) and ease of access to trails, were not tested as deterrents to hiking activity. 
Furthermore, the study did not compare the differences between a branded, independent accreditation system (the case study) and other forms of trail grading currently in place to determine whether the various forms of information provision platforms hold different perceived levels of credibility. In addition, behavioral intentions (future hiking purchases) were tested as opposed to actual behavior. The data analysis also presents limitations in terms of the use of nonparametric tests as opposed to more stringent parametric tests. Exploring whether the presence of an accreditation system would lead to future purchase behavior was only done at the hand of descriptive statistics and no further inferential statistics were used to explore differences in this regard between respondent groups (based on safety perceptions, importance of accreditation, frequency of hiking). Future research could aim to use more sophisticated data analysis techniques such as structural equation modeling to test the simultaneous influence of accreditation and safety concerns, as well as other relevant constraints (such as costs, social norms, level of involvement in hiking, involvement in decision-making, etc.), on future purchase intentions, thereby testing the relative importance of safety and risk perceptions compared to other influencing factors. Lastly, the South African scenario presents a unique perspective in terms of safety issues, which could lead to distinct emphasis on certain aspects of risk. Testing for differences in the importance/preference regarding varied categories of risk related information across different settings could be an avenue worth exploring.

\section{References}

Adam, I. (2015). Backpackers' risk perceptions and risk reduction strategies in Ghana. Tourism Management, 49, 99-108.

American Hiking Society. (2014). Mission statement. Retrieved from: http://www.americanhiking.org/about-us/ our-mission/

Beeco, J. A., Hallo, J. C., Baldwin, E. D. \& McGuire, F. A. (2011). An examination of the guided night hiking experience in parks and protected areas. Journal of Park and Recreation Administration, 29(4), 72-88.

Beeton, S. (2001). Horseback tourism in Victoria, Australia: Cooperative, proactive crisis management. Current Issues in Tourism, 4, 422-439.

Bentley, T. A., \& Page, S. (2008). A decade of injury monitoring in the New Zealand adventure tourism sector: A summary risk analysis. Tourism Management, 29, 857-869.
Bentley, T. A., Page, S., \& Walker, L. (2004). The safety experience of New Zealand adventure tourism operators. Journal of Travel Medicine, 11(5), 280-286.

Bergin, S., \& Jago, L.K. (1999). Accreditation of adventure tour operators: The consumer perspective. In CAUTHE 1999: Delighting the Senses; Proceedings from the Ninth Australian Tourism and Hospitality Research Conference (pp. 223-234). Canberra, Australia: Bureau of Tourism Research.

Bergin-Seers, S. \& Mair, J. (2009). Emerging green tourists in Australia: Their behaviours and attitudes. Tourism and Hospitality Research, 9(2), 109-119.

Boulware, D. R., Forgey, W. W., \& Martin, W. J. (2003). Medical risks of wilderness hiking. The American Journal of Medicine, 114(4), 288-293.

Brand South Africa. (2003). Hiking in South Africa. Retrieved from http://www.southafrica.info/travel/adventure/hiking. htm\#.U3EKxXYXIYc

Buckley, R. (2002). Tourism ecolabels. Annals of Tourism Research, 29(1), 183-208.

Buckley, R. (2006). Adventure tourism. Oxfordshire, UK: CAB International.

Buckley, R. (2010). Adventure tourism management. Amsterdam/Boston: Butterworth-Heinemann/Elsevier.

Buckley, R. (2012). Rush as a key motivation in skilled adventure tourism: Resolving the risk recreation paradox. Tourism Management, 33(4), 961-970.

BuzzFeed Inc. (2014). 16 Astounding Backpacking Trips to Add to Your Bucket List. Retrieved from: https://www. buzzfeed.com/ariannarebolini/astounding-backpackingtrips?utm_term=.lo1QLYWNn\#.jw7Vz3BPG

Cater, C. I. (2006). Playing with risk? Participant perceptions or risk and management implications in adventure tourism. Tourism Management, 27(2), 317-325.

Chen, J. S., \& Gursoy, D. (2000). Cross-cultural comparison of the information sources used by first-time and repeat travelers and its marketing implications. International Journal of Hospitality Management, 19(2), 191-203.

Chhetria, P., Arrowsmith, C., \& Jackson, M. (2004). Determining hiking experiences in nature-based tourist destinations. Tourism Management, 25(1), 31-43.

Chia-Jung, C., \& Pei-Chun, C. (2014). Preferences and willingness to pay for green hotel attributes in tourist choice behavior: The case of Taiwan. Journal of Travel \& Tourism Marketing, 31(8), 937-957.

Colbe, T. G., Selin, S. W., \& Erickson, B. B. (2003). Hiking alone: Understanding fear, negotiation strategies and leisure experience. Journal of Leisure Research, 35(1), $1-22$.

Dickson, T., \& Dolnicar, S. (2004). No risk, no fun the role of perceived risk in adventure tourism. (2004). In Cooper, C. (Ed.), CAUTHE 2004: Creating Tourism Knowledge (pp. 184-189). Brisbane, Australia: Common Ground Publishing.

Edwards, D. (2016). Track grading. Retrieved from: www. trailhiking.com.au/preparing-to-hike/track-grading/.

Ernest, D. J., Level, A. V. \& Culbertson, M. (2005). Information-seeking behavior for recreational activities and 
its implications for libraries. Reference Services Review, 33(1), 88-103.

Fairweather, J. R., Maslin, C., \& Simmons, D. G. (2005). Environmental values and response to ecolabels among international visitors to New Zealand. Journal of Sustainable Tourism, 13(1), 82-98.

Fodness, D., \& Murray, B. (1997). Tourist information search. Annals of Tourism Research, 24(3), 503-523.

Font, X. (2002). Environmental certification in tourism and hospitality: Progress, process and prospects. Tourism Management, 23(3), 197-205.

Foster, D. (2003). The customer's perception of tourism accreditation. Melbourne: RMIT University, Centre for Management Quality Research. Retrieved from: http:// mams.rmit.edu.au/2ulaujpi756m.pdf

Fredman, P., Wall-Reinius, S., \& Grundén, A. (2012). The nature of nature in nature-based tourism. Scandinavian Journal of Hospitality and Tourism, 12(4), 289-309.

Fuchs G., \& Reichel A. (2006). Tourist destination risk perception: The case of Israel. Journal of Hospitality and Leisure Marketing, 14(2), 81-106.

George, R. (2004). Marketing South African tourism (2nd ed.). Cape Town, South Africa: Oxford University Press Southern Africa.

Gibson, H. J. (2004). Moving beyond the "what is and who" of sport tourism to understanding "why". Journal of Sport Tourism, 9(3), 247-265.

Gursoy, D., \& Chen, J. S. (2000). Competitive analysis of crosscultural information search behaviour. Tourism Management, 21(6), 583-590.

Gursoy, D., \& McCleary, K. W. (2004). An integrative model of tourists' information search behavior. Annals of Tourism Research, 31(2), 353-373.

Gursoy, D., \& Umbreit, W. T. (2004). Tourist information search behavior: Cross-cultural comparison of European union member states. International Journal of Hospitality Management, 23(1), 55-70.

Hales, C., \& Shams, H. (1991). Cautious incremental consumption: A neglected consumer risk reduction strategy. European Journal of Marketing, 25(7), 7-21.

Hamonko, M. T., McIntosh, S. E., Schimelpfenig, T., \& Leemon, D. (2011) Injuries related to hiking with a pack during National Outdoor Leadership School courses: A risk factor analysis. Wilderness and Environmental Medicine, 22(2011), 2-6.

Hartwright, T. (2014). Gauteng hikes and walks-guide to walks and hikes in and around Gauteng. Auckland Park, South Africa. Jacana Media.

Heggie, T. W., \& Heggie, T. M. (2012). Dead man hiking: Case studies from the American Wilderness. Medicina Sportiva, 16(3), 118-121.

Howard, P. H., \& Allen, P. (2008). Consumer willingness to pay for domestic 'fair trade': Evidence from the United States. Renewable Agriculture and Food Systems, 23(3), 235-242.

Hugo, M. L. (1999a). A comprehensive approach towards the planning, grading and auditing of hiking trails as ecotourism products. Current Issues in Tourism, 2(2-3), 138-173.
Hugo, M. L. (1999b). Energy equivalent as a measure of the difficulty rating of hiking trails. Tourism Geographies, 1(3), 358-373.

Hunter-Jones, P., Jeffs, A., \& Smith, D. (2007). Backpacking your way into crisis: An exploratory study into perceived risk and tourist behavior amongst young people. Journal of Travel \& Tourism Marketing, 23(2/4), 237-248.

Imboden, A. (2012) Between risk and comfort: Representations of adventure tourism in Sweden and Switzerland. Scandinavian Journal of Hospitality and Tourism, 12(4), 310-323.

Jun, S. H., Vogt, C. A., \& MacKay, K. J. (2007). Relationships between travel information search and travel product purchase in pretrip contexts. Journal of Travel Research, 45(3), 266-274.

Kastenholz, E., \& Rodrigues, Á. (2007). Discussing the potential benefits of hiking tourism in Portugal. Anatolia, 18(1), 5-21.

Kerstetter, D., \& Cho, M. (2004). Prior knowledge, credibility and information search. Annals of Tourism Research, 31(4), 961-985.

Kozak, M., \& Nield, K. (2004). The role of quality and ecolabelling systems in destination benchmarking. Journal of Sustainable Tourism, 12(2), 138-148.

Lacher, R. (2012). Serious tourism and consumer preferences for sustainable tourism certifications. Unpublished doctoral thesis, Clemson University, Clemson, South Carolina.

Leedy, P. D., \& Ormrod, J. E. (2014). Practical research: Planning and design. Harlow, UK: Pearson.

Leonard, D. (2011). A study into the motivations for participation in environmental certification schemes by the tourist accommodation sector. Thesis for Bachelor of Business Administration, Modul University, Vienna, Austria. Retrieved from https://www.modul.ac.at/uploads/ files/Theses/Bachelor/THESIS-_DAVID_LEONARD_. pdf

Lewis-Beck, M., Bryman, A. E., \& Liao, T. F. (2003). The SAGE encyclopedia of social science research methods. Thousand Oaks, CA: SAGE Publications.

Lipscombe, N. (1995). Appropriate adventure: Participation for the aged. Australian Parks and Recreation, 31(2), 41-45.

Lundmark, L., \& Müller, D. K. (2010). The supply of naturebased tourism activities in Sweden. Tourism, 58(4), 379-393.

Lundy, M. (2012). Mike Lundy's best walks in the Cape Peninsula (8th ed.). Cape Town, South Africa: Random House Struik.

Luthe, T., \& Schläpfer, F. (2011). Effects of third-party information on the demand for more sustainable consumption: A choice experiment on the transition of winter tourism. Environmental Innovation and Societal Transitions, 1(2), 234-254.

Magyari-Sáska, Z. (2014). Quantifying threats along tourist trails: An initial approach. Geographia Technica, 9(1), 78-86.

Marchoo, W., Butcher, K., \& Watkins, M. (2014). Tour booking: Do travelers respond to tourism accreditation 
and codes of ethics initiatives? Journal of Travel \& Tourism Marketing, 31(1), 16-36.

Martin, P., \& Priest, S. (1986). Understanding the adventure experience. Journal of Adventure Education, 3(1), $18-21$.

Maser, B., \& Weiermair, K. (1998). Travel decision-making: From the vantage point of perceived risk and information preferences. Journal of Travel \& Tourism Marketing, 7(4), 107-121.

Miller, G. A. (2003). Consumerism in sustainable tourism: A survey of UK consumers. Journal of Sustainable Tourism, 11(1), 17-39.

Mlozi, S., \& Pesämaa, O. (2013). Adventure tourist destination choice in Tanzania. Current Issues in Tourism, 16(1), 63-95.

Moutinho, L., Ballantyne, R., \& Rate, S. (2011). Consumer behaviour in tourism. In: Moutinho, L. (Eds), Strategic management in tourism (2nd ed.). Oxfordshire, UK: CAB International.

Morgan, D., \& Dimmock, K. (2006). Risk management in outdoor adventure tourism. In J. Wilks, D. Pendergast, \& P. Leggat (Eds.), Tourism in turbulent times (pp. 171185). New York, NY: Taylor \& Francis.

Morgan, D., \& Fluker, M. (2003). Risk management for Australian commercial adventure tourism operations. Journal of Hospitality and Tourism Management, 10(1), 46-60.

Morgan, D., Moore, K., \& Mansell, R. (2005). Adventure tourists on water: Linking expectations, affect, achievement and enjoyment to the sports tourism adventure. Journal of Sport Tourism, 10(1), 73-88.

Mowen, J., \& Minor, M. (1998). Consumer behavior. Upper Saddle River, NJ: Prentice Hall.

Mura, P. (2010). 'Scary . . . but I like it!' Young tourists' perceptions of fear on holiday. Journal of Tourism and Cultural Change, 8(1-2), 30-49.

Mura, P., \& Cohen, A. S. (2011). Introduction to special issue on 'leisure, tourism and risk'. Recreation and Society in Africa, Asia and Latin America, 1(2), 1-6.

National Geographic Society. (2014). World's best hikes: Epic trails. Retrieved from: http://www.nationalgeogra phic.com/adventure/trips/best-trails/worlds-best-grailtrails/

Nordbø, I., Engilbertsson, H. O., \& Vale, L. S. R. (2014). Market myopia in the development of hiking destinations: The case of Norwegian DMOs. Journal of Tourism Marketing and Management, 23(4), 380-405.

Olivier, W. (2010). Hiking trails of South Africa (3rd ed.). Cape Town, South Africa: Random House Struik.

Patterson, I., \& Pan, R. (2007). The motivations of baby boomers to participate in adventure tourism and the implications for adventure tour providers. Annals of Leisure Research, 10(1), 26-53.

Perdue, R. R. (1985). Segmenting state information inquirers by timing of destination decision and previous experience. Journal of Travel Research, 23(3), 6-11.

Puhakka, R., \& Siikamäki, P. (2012). Nature tourists' response to ecolabels in Oulanka PAN Park, Finland. Journal of Ecotourism, 11(1), 56-73.
Raitz, K., \& Dakhil, M. (1989). A note about information sources for preferred recreational environments. Journal of Travel Research, 27(1), 45-49.

Ritchie, B., \& Adair, D. (2002). The growing recognition of sport tourism. Current Issues in Tourism, 5(1), 1-6.

Rupf, R., Haider, W., \& Pröbstl, U. (2014). Hikers and mountain bikers-do they fight like cats and dogs? In M. Reimann, K. Sepp, E. Pärna, \& R. Tuula (Eds.), The 7th International Conference on Monitoring and Management of Visitors in Recreational and Protected Areas (MMV) (pp. 253-255). Retrieved from http://www.tlu. ee/en/MMV7/

Ryan, C. (2003). Risk acceptance in adventure tourism: paradox and context. In J. Wilks, J. Stephen, \& F. Moore, F. (Eds.), Managing tourist health and safety in the new millennium (pp. 55-67). Oxford, UK: Elsevier.

Saayman, M., \& Viljoen, A. (2016). Who are wild enough to hike a wilderness trail? Journal of Outdoor Recreation and Tourism, 14, 41-51.

Saunders, M., Lewis, P., \& Thornhill, A. (2012). Research methods for business students (6th ed.). Harlow, UK: Pearson Education.

Schiffman, L., \& Kanuk, L. (2007). Consumer behavior (9th ed.). Upper Saddle River, NJ: Prentice Hall.

Schmidt, J. B., \& Spreng, R. A. (1996). A proposed model of external consumer information search. Journal of the Academy of Marketing Science, 24(3), 246-256.

Schul, P., \& Crompton, J. L. (1983). Search behavior of international vacationers: Travel-specific lifestyle and sociodemographic variables. Journal of Travel Research, 22(3), 25-31.

Sharifpour, M., Walters, G., Ritchie, B. W., \& Winter, C. (2014). Investigating the role of prior knowledge in tourist decision making a structural equation model of risk perceptions and information search. Journal of Travel Research, 53(3), 307-322.

Snepenger, D., Meged, K., Snelling, M., \& Worrall, K. (1990). Information search strategies by destination-naïve tourists. Journal Travel Research, 29(1), 13-16.

South African National Parks. (2015). Hiking and nature walks. Retrieved from https://www.sanparks.org/tourism/ activities/hiking.php

Standeven, J., \& De Knop, P. (1999). Sport tourism. Champaign/IL: Human Kinetics.

Swarbrooke, J., Beard, C., Leckie, S., \& Pomfret, G. (2003). Adventure tourism the new frontier. Oxford, UK: Butterworth-Heinemann/Elsevier Science Ltd.

Thapa, B., Graefe, A. R., \& Absher, J.D. (2002). Information needs and search behaviors: A comparative study of ethnic groups in the Angeles and San Bernardino National Forests, California. Leisure Sciences, 24(1), 89-107.

Top 10 hiking trails in the world. (2014). Retrieved from http://www.placestoseeinyourlifetime.com/top-10hiking-trails-in-the-world-2411/

Tsaur, S. H., Lin, W., \& Liu, J. (2013). Sources of challenge for adventure tourists: Scale development and validation. Tourism Management, 38, 85-93. 
Tyrväinen, L., Uusitalo, M., Silvennoinen, H., \& Hasu, E. (2014). Towards sustainable growth in nature-based tourism destinations: Clients' views of land use options in Finnish Lapland. Landscape and Urban Planning, 122, 1-15.

Uriely, N., Schwartz, Z., Cohen, E., \& Reichel, A. (2002). Rescuing hikers in Israel's deserts: Community altruism or an extension of adventure tourism? Journal of Leisure Research, 34(1), 25-36.

United Nations World Tourism Organization. (2014). Global report on adventure tourism. Retrieved from http://affil iatemembers.unwto.org/publication/global-report-adven ture-tourism

US Forest Service. (2016). USDA Forest Service standard trail plans and specifications. Retrieved from http://www.fs.fed. us/recreation/programs/trail-management/trailplans/
Walkopedia. (2015). Best walks, hikes and treks in South Africa. Retrieved from http://www.walkopedia.net/walks/ full-list/country-list.asp?country=South\%20Africa

Williams, P., \& Soutar, G. (2005). Close to the “edge”: Critical issues for adventure tourism operators. Asia Pacific Journal of Tourism Research, 10(3), 247-261.

Williams, P., \& Soutar, G. N. (2009). Value, satisfaction and behavioral intentions in an adventure tourism context. Annals of Tourism Research, 36(3), 413-438.

Zillifro, T., \& Morais, D. B. (2004). Building customer trust and relationship commitment to a nature-based tourism provider: The role of information investments. Journal of Hospitality \& Leisure Marketing, 11(2-3), 159-172. 